Vol. 7(1998): 455-468.

\title{
Description of three new arctic bramble cultivars and proposal for cultivar identification
}

Heli Pirinen

Department of Biochemistry and Biotechnology, University of Kuopio, PO Box 1627, FIN-70211 Kuopio, Finland, e-mail: heli.pirinen@agronet.fi

Pirjo Dalman

Agricultural Research Centre of Finland, Resource Management Research, Ecological Production, FIN-50600 Mikkeli, Finland

Sirpa Kärenlampi

Department of Biochemistry and Biotechnology, University of Kuopio, PO Box 1627, FIN-70211 Kuopio, Finland

Jussi Tammisola

Department of Plant Biology, PO Box 27, FIN-00014 University of Helsinki, Finland

Harri Kokko

Department of Biochemistry and Biotechnology, University of Kuopio, PO Box 1627, FIN-70211 Kuopio, Finland

\begin{abstract}
Morphological and yield differences between five arctic bramble (Rubus arcticus L.) strains and the cultivars Pima and Mespi were studied at two locations during the growing season 1994. Morphological observations and measurements were made on canes, leaves, flowers and berries, adapting the UPOV (Union pour la Protection des Obtentions Vegetales) descriptions for strawberry and raspberry. The plants were also compared with the aid of random amplified polymorphic DNA analysis. Apart from DNA, the most important distinctive characteristic was yield. Characteristics of the flowers, leaves and berries, such as number, size, shape and colour were used to differentiate between the arctic bramble genotypes. The yield of three new cultivars, named Marika, Muuruska and Elpee, was greater than that of Pima or Mespi. The yield of 'Marika' and 'Elpee' was 2,4-times and that of 'Muuruska' 1,9-times that of 'Pima' or 'Mespi'. Based on distinctive morphological characteristics, guidelines for the description of arctic bramble are proposed. This description may also be used for hybrids of arctic bramble with Rubus stellatus Sm., i.e. Rubus arcticus L. nothosubsp. stellarcticus G. Larsson.
\end{abstract}

Key words: morphology, RAPD, Rubus arcticus, UPOV, yields 


\section{Introduction}

In Finland, arctic bramble (Rubus arcticus L.) is cultivated in an area of ca. 20 hectares (Finnish Association of Fruit and Berry Growers, pers. comm. 1996, Hannu Salo) between latitudes $62^{\circ}$ and $66^{\circ}$ N. Kokko et al. (1993) have estimated that the income from arctic bramble could be $c a$. FIM 200,000/year/hectare, which is six times that from strawberry (Fragaria $x$ ananassa Duch.) and five times that from red raspberry (Rubus idaeus L.), (Information Centre of the Ministry of Agriculture and Forestry 1996). Arctic bramble is mainly grown under contract by the liqueur and juice industry; because of the low production volumes, it has not been exported as berries. There is a need for new high-yielding cultivars, only two cultivars having thus far been commercially available, i.e. 'Mespi' (Ryynänen 1972) and 'Pima' (Ryynänen and Dalman 1983). Arctic bramble is a self-incompatible diploid plant. 'Pima' is a cross between 'Mespi' and 'Mesma', and thus contains one self-incompatibility gene in common with 'Mespi'. Consequently, only half of the pollen can fertilise the ovule (Paasisalo and Kokko 1991). To ensure better cross-pollination and maximum yield, arctic bramble should preferably be grown as a mixed population of at least three unrelated clones (Tammisola 1988).

For a new cultivar of a horticultural crop to be described and released it has to differ from the other cultivars of the same species in one or more characteristics. The differences can be morphological, physical, cytological, chemical or biochemical. The description process must be similar for all cultivars within a species. Detailed descriptions exist for the identification of strawberry and raspberry cultivars (UPOV 1984, 1986), but no guidelines are available for arctic bramble. The aims of the present study were 1) to select and release new superior arctic bramble cultivars, and 2) to develop guidelines for the description of arctic bramble by adapting the respective instructions for strawberry and raspberry given by UPOV (Union pour la Protection des Obtentions Vegetales).

\section{Materials and methods}

\section{Experimental areas, cultivars and strains}

Morphological differences between arctic bramble cultivars and strains were studied in summer 1994 at two locations: the Kainuu Research Station of the Agricultural Research Centre of Finland in Sotkamo $\left(64^{\circ} 06^{\prime} \mathrm{N}\right.$ and $\left.28^{\circ} 24^{\prime} \mathrm{E}\right)$ (Experiment III) and the School of Agriculture and Horticulture in Muuruvesi $\left(63^{\circ} 01^{\prime} \mathrm{N}\right.$ and $\left.28^{\circ} 13^{\prime} \mathrm{E}\right)$ (Experiments I and II).

On the basis of studies on around 300 wild arctic bramble strains (Tammisola 1988), the best 100 strains were planted at the Agricultural Research Station in Mikkeli in 1980. The seventeen most promising of these strains were then selected for further investigation. The present study included the two cultivars, i.e. Mespi and Pima, and five wild strains: No. 4 = 'Marika' (origin Laukaa), No. 33 = 'Muuruska' (origin Kiiminki), No. 39 (origin Hauho), No. 57 (origin Tammela) and No. 77 = 'Elpee' (origin Konnevesi). These plants were among the seventeen wild strains studied at six locations during 19911992 (Kokko et al. 1993). Here, Experiments I and II included strains 57, 39, 33, 77 and 4 and 'Pima' and 'Mespi'; Experiment III included strains 57, 39, 33 and 'Mespi' and 'Pima'. The strains and cultivars were propagated vegetatively in tissue culture (Kokko et al. 1993, Kokko et al. 1996).

\section{Planting and cultivation of arctic bramble}

In Experiment III, the soil was silt with a $\mathrm{pH}$ value of 6.5; before planting, $500 \mathrm{~kg} / \mathrm{ha}$ NPK fertilizer (7-5-15) was applied. In Experiments I and II, the soil was humous silty clay, and no fertilisation was applied during the establishment phase. Experiment I was planted in 1990 and Experiments II and III were planted in 1991. In all experiments, the plants were planted in 
Vol. 7 (1998): 455-468.

$0.1 \mathrm{~m}$ high beds with a top width of $0.6 \mathrm{~m}$. In Experiment I, each plot was $10.0 \mathrm{~m}$ long, with a spacing of $0.33 \mathrm{~m}$ between the plants and 1.0$1.2 \mathrm{~m}$ between the rows. In Experiments II and III, each plot was $5.0 \mathrm{~m}$ long, with spacing of $0.33 \mathrm{~m}$ between the plants and $1.5 \mathrm{~m}$ between the rows. The distance between the plots was 0.5 $\mathrm{m}$. The beds were covered with black plastic cover mulch. Planting was done in 13 x $13 \mathrm{~cm}$ holes, new holes were made in the beginning of the second growing season to ensure spreading of the plants. In Experiment III, the soil surface between the plastic ridges was covered by grass mulch. To secure pollination, every third plant was 'Pima', except in the 'Pima' plots, where the pollinator plant was 'Mespi'. The plots were totally randomised except in Experiment $I$ in Muuruvesi, which was partly randomised. There were two replicates from test clones and four replicates from 'Pima' and 'Mespi' in Experiment I. Experiments II and III had three replicates. A beehive was located near the site of Experiments III and I to ensure pollination. No pesticides were used and plots were weeded manually.

\section{Morphological observations and measurements}

Twenty samples were taken from each strain and cultivar (Table 1), excluding the pollinator plants, for morphological observations. The berries were collected from the whole plot, the pollinator plants included. Experiments I and II in Muuruvesi were considered as one experiment for morphological observations and measurements. The yields, however, were recorded separately for each experiment. Shoot emergence was observed during May. Observations were made at the beginning of flowering, from fully open flowers, at the beginning of harvest and during the second harvest. Samples were collected, and parameters and measurements were taken on the leaves, shoots, flowers and berries. The length and breadth of the middle leaflet, and the shape of the leaf base and teeth were measured on pressed leaves. The sweetness and acidity of the fruits from the second harvest were evaluated with a sensory test. The berries were picked once or twice a week depending on weather conditions, and the yield was weighed.

\section{Analysis by random amplified polymorphic DNA (RAPD)}

DNA was isolated from arctic bramble leaves following the procedure described by Doyle and Doyle (1990). The isolated DNA samples were subjected to the Polymerase Chain Reaction (PCR) using commercial random 10-mer primers (Operon Technologies, Inc oligo 10-mer kit $\mathrm{D}$ and $\mathrm{E})$. One $\mu \mathrm{l}$ (20 ng) of template (plant) DNA and $14 \mu \mathrm{l}$ of the reaction mixture (dNTP, OP primer, Dynabuffer) were added to the PCR tube and overlayed with $25 \mu \mathrm{l}$ of melted Dynawax. After the wax had hardened, $10 \mu$ of enzyme mixture (Dynabuffer and Dynazyme) was added to it. The final PCR reaction $(25 \mu \mathrm{l})$ contained Dynabuffer (10 mM Tris-HCl, pH 8.8, $1.5 \mathrm{mM} \mathrm{MgCl}_{2}, 50 \mathrm{mM} \mathrm{KCl}, 0.1 \%$ Triton $\mathrm{X}$ 100), $200 \mu \mathrm{M}$ dNTPs, 5 pmol OP-primer, $20 \mathrm{ng}$ template DNA and $1 \mathrm{U}$ of Dynazyme DNA polymerase. After initial denaturation (1 $\mathrm{min}$ at $96^{\circ} \mathrm{C}$ ), 39 cycles of PCR (denaturation, $20 \mathrm{sec}$ at $94^{\circ} \mathrm{C}$; annealing, $1 \mathrm{~min}$ at $38,5^{\circ} \mathrm{C}$; synthesis, $1 \mathrm{~min}$ at $72^{\circ} \mathrm{C}$ ) were run in a thermal cycler. Amplified DNA was analysed by electrophoresis in $1.2 \%$ agarose and detected by ethidium bromide staining. Amplified PCR fragments obtained with primers (OPD-3, OPD-5 and OPE19) were scored for their intensity: absence 0 , presence 1 . Genetic distance was calculated with the GENDIST program of PHYLIP package version $3.5 \mathrm{c}$ by Nei's distance. The dendrogram of Rubus arcticus strains and cultivars was drawn by Neighbor-Joining method.

\section{Statistical methods}

The results were subjected to analysis of variance at the $5 \%$ risk level by SAS. Subsequently, 


\section{Pirinen, H. et al. Description of arctic bramble cultivars}

Table 1. Parameters observed on R. arcticus clones and cultivars.

\begin{tabular}{|c|c|c|c|c|c|}
\hline \multicolumn{6}{|c|}{ Observations at the beginning of flowering } \\
\hline \multirow{2}{*}{$\begin{array}{l}\text { Beginning of flowering } \\
\text { Plant density }\end{array}$} & \multicolumn{5}{|c|}{ 3-5 flowers/ plot are open } \\
\hline & $1=$ very scanty & $3=$ scanty & $5=$ medium & $7=$ dense & $9=$ very dense \\
\hline \multicolumn{6}{|l|}{ Observations on fully open flowers } \\
\hline \multicolumn{6}{|l|}{ Number of petals } \\
\hline \multicolumn{6}{|l|}{ Diameter of flower (mm) } \\
\hline Flower profusion & $1=$ few or none & $2=$ few flowers & $3=$ medium & 4=abundantly & $\begin{array}{l}5=\text { very } \\
\text { abundantly }\end{array}$ \\
\hline Anthocyanin coloration & $1=$ absent & $9=$ present & & & \\
\hline Intensity of anthocyanin coloration & $1=$ very weak & $2=$ weak & $3=$ medium & $4=$ strong & $5=$ very strong \\
\hline Flower position relative to foliage & $3=$ beneath & $5=$ level with & $7=$ above & & \\
\hline Size of calyx relative to corolla & $3=$ smaller & $5=$ same size & $7=$ larger & & \\
\hline Spacing of petals & $3=$ free & $5=$ touching & $7=$ overlapping & & \\
\hline
\end{tabular}

Observations at the beginning of harvest

Covering point

Number of canes on the area of $10 \times 10 \mathrm{~cm}$

Cane length $(\mathrm{cm})$

Length of middle leaflet $(\mathrm{mm})$

Breadth of middle leaflet $(\mathrm{mm})$

$\begin{array}{llll}\text { Vigour of growth } & 1=\text { dead or very weak } & 3=\text { weak } & \text { 5=medium } \\ \text { Relief between veins of leaf } & 1=\text { very weak } & 3=\text { weak } & 5=\text { medium } \\ \text { Overlapping of lateral leaflets } & 3=\text { free } & 5=\text { touching } & 7=\text { overlapping } \\ \text { Green colour of upper side of leaf } & 3=\text { light } & 5=\text { medium } & 7=\text { dark } \\ \text { Cross section of leaf } & 1=\text { concave } & 3=\text { slightly concave } 5=\text { flat } & 7=\text { rounded } \\ \text { Shape of leaf base } & 3=\text { acute } & 5=\text { obtuse } & 7=\text { rounded }\end{array}$

Observations at the second harvest

Length of berry (mm)

Breadth of berry $(\mathrm{mm})$

Weight of berry ( $g$ )

Fruit colour

$1=$ greenish

$6=$ dark red

Insertion of calyx

$3=$ in a basin

Size of calyx in relation to fruit diameter

Fruit sweetness

$3=$ smaller

$3=$ weak

Fruit acidity

3 =weak

Adapted from strawberry and raspberry descriptions of UPOV (Union pour la Protection des Obtentions Vegetales) (UPOV 1984, 1986).

significant differences from Pima' were determined with Dunnett's test. In addition, correlation analysis was applied for continuous variables by SPSS. The results denoted by ** correlate significantly at the 0.01 level and * at the 0.05 level.

\section{Results}

\section{Yield}

In 1994, fruiting of arctic bramble started on 18 July and ended on 25 August. The main yield 
Vol. 7 (1998): 455-468.

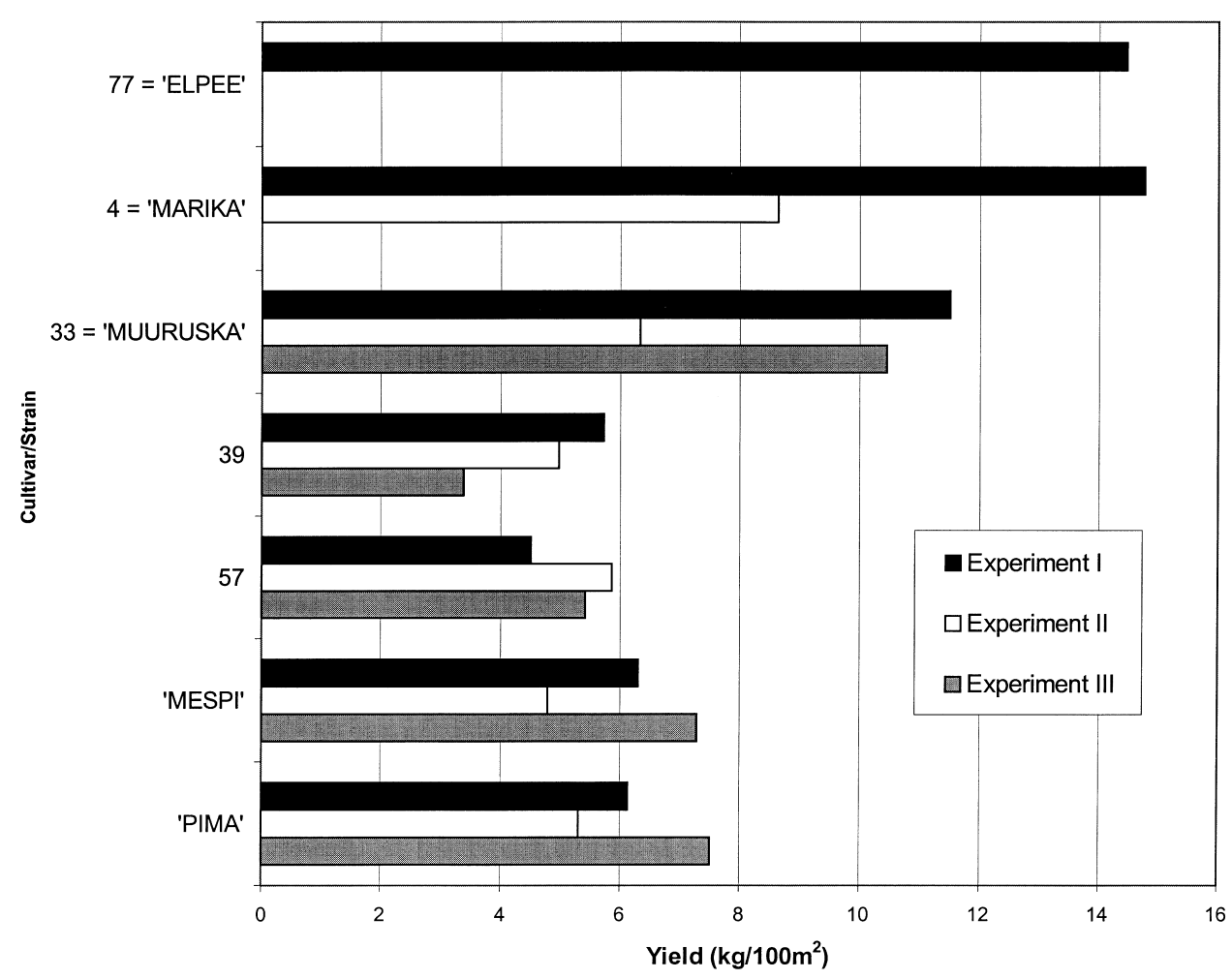

Fig. 1. Yields $\left[\mathrm{kg} / 100 \mathrm{~m}^{2}\right]$ of $R$. arcticus strains in Experiments I and II at the School of Agriculture and Horticulture in Muuruvesi and in Experiment III at the Kainuu Research Station of the Agricultural Research Centre in Sotkamo during growing season 1994.

ripened at the end of July and beginning of $\mathrm{Au}-$ gust. Higher yields were collected from strains 33, 4 and 77 (Experiment I: $\mathrm{F}=4.96, \mathrm{P}=0.0001$; Experiment III $\mathrm{F}=19.7, \mathrm{P}=0.0003$ ) (Fig. 1) than from 'Pima'. In Experiment III, the yield showed a negative correlation with flower size $(r=$ $-0.43 * *)$ and the petal number $(\mathrm{r}=-0.27 * *)$ whereas berry breadth $\left(\mathrm{r}=0.33^{* *}\right)$, berry length $(\mathrm{r}=0.22 *)$, berry weight $(\mathrm{r}=0.31 * *)$, and middle leaflet breadth $(\mathrm{r}=0.42 * *)$ and length $(\mathrm{r}=0.22 *)$ correlated positively with yield.

\section{Berries}

The biggest fruits were in strain 33 (Table 2). In Experiments I, II and III, berry weight correlated positively with berry length $\left(\mathrm{r}=0.85^{* *}\right.$, $\left.\mathrm{r}=0.76^{* *}\right)$ and breadth $\left(\mathrm{r}=0.85^{* *}, \mathrm{r}=0.75^{* *}\right)$; berry length and breadth also correlated positively $\left(\mathrm{r}=0.81^{* *}, \mathrm{r}=0.64 * *\right)$. In Experiment III, the correlation between berry weight and flower size was negative $(\mathrm{r}=-0.27 * *)$; likewise berry length $\left(\mathrm{r}=-0.20^{*}\right)$ and breadth $\left(\mathrm{r}=-0.33^{* *}\right)$ correlated negatively with flower size. The number of petals correlated negatively with berry weight $(r=$ $-0.24 * *)$ and breadth $\left(\mathrm{r}=-0.38^{* *}\right)$. The colour of the ripe berries varied from different tones of red to yellow or green or mixtures of the two. No particular fruit colour was typical of any of the strains, although strains 4 and 77 had a clear green shade. In the sensory tests of the berries from Experiment III, the sweetest and most acidic fresh berries were in strains 57 and 39; 'Pima', too, was quite acidic. In Experiments I and II, strain 33 was the sweetest but in Experiment III its taste was only medium sweet. Fruit sweetness and acidity were weakest in strain 77 . 
Pirinen, H. et al. Description of arctic bramble cultivars

Table 2. Morphological measurements of leaves, flowers and berries of arctic bramble $(\mathrm{n}=20)$. Means denoted by * are significantly different from 'Pima' at $\mathrm{P}=0.05$ according to Dunnett's test.

\begin{tabular}{|c|c|c|c|c|c|c|}
\hline \multirow[t]{2}{*}{ Strain } & \multicolumn{2}{|c|}{$\begin{array}{l}\text { Length of } \\
\text { middle leaflet } \\
\mathrm{mm}\end{array}$} & \multicolumn{2}{|c|}{$\begin{array}{l}\text { Breadth of } \\
\text { middle leaflet } \\
\text { mm }\end{array}$} & \multicolumn{2}{|c|}{ Diameter of flower } \\
\hline & $\begin{array}{l}\text { Experi- } \\
\text { ments I,II }\end{array}$ & $\begin{array}{l}\text { Experi- } \\
\text { ment III }\end{array}$ & $\begin{array}{l}\text { Experi- } \\
\text { ments I,II }\end{array}$ & $\begin{array}{l}\text { Experi- } \\
\text { ment III }\end{array}$ & $\begin{array}{c}\text { Experi- } \\
\text { ments I,II }\end{array}$ & $\begin{array}{l}\text { Experi- } \\
\text { ment III }\end{array}$ \\
\hline 'Pima' & 41.1 & 39.5 & 29.6 & 27.0 & 21.5 & 25.2 \\
\hline ‘Mespi’ & 39.8 & 36.3 & 28.8 & 26.0 & 21.0 & $22.4 *$ \\
\hline strain 33 'Muuruska' & 41.2 & 38.9 & $24.9 *$ & 24.6 & 21.9 & $19.4 *$ \\
\hline strain 57 & 40.2 & $33.0^{*}$ & 27.3 & $21.4^{*}$ & 21.8 & 26.9 \\
\hline strain 39 & 38.8 & $35.6^{*}$ & $23.1^{*}$ & $22.1 *$ & 23.4 & $27.7^{*}$ \\
\hline strain 77 'Elpee' & 39.3 & & 26.8 & & 22.5 & \\
\hline strain 4 'Marika' & 40.2 & & $24.4^{*}$ & & $24.7 *$ & \\
\hline $\mathrm{F}$ & 0.40 & 6.23 & 4.22 & 6.74 & 2.9 & 38.33 \\
\hline $\mathrm{P}$ & 0.8758 & 0.0002 & 0.0007 & 0.0001 & 0.0120 & 0.0001 \\
\hline
\end{tabular}

\section{Leaves}

Strains 57 and 39 had the shortest and most angustifolious middle leaflets (Table 2), and strains 33 and 4 were more narrow-leaved than 'Pima'. In both Experiments, the length and breadth of the middle leaflet correlated positively $\left(\mathrm{r}=0.66^{* *}\right.$, $\left.\mathrm{r}=0.73^{*}\right)$. In Experiments I and II, the length of the middle leaflet correlated negatively with the number of petals $(\mathrm{r}=0.21 *)$. The leaves were the darkest greenish shade in strain 39 and the lightest in strain 33 (Fig. 2). The cross-section of the leaf was generally concave or slightly concave, but in strain 4 it was clearly flat. Strain 77 had slightly convex cross-sections. Overlapping of lateral leaflets was most prominent in strains 33 and 39. The lateral leaflets of strain 4 did not touch each other (Fig. 3). Strain 4 had the most acute base and teeth in the leaf; 'Mespi' and 'Pima' had more rounded teeth (Fig. 4).

\section{Flowering and flowers}

Flowering started in early June and continued through July and August. Strains 33 and 4 were both rich in flowers, but strain 57 flowered most abundantly. The largest flowers were in strain 39 (Table 2). Although the flower diameter was also wide in strains 33 and 4 and in the cultivar
Mespi, the number of petals was lower than in strain 39 (Table 2). However, the flower size and number of petals correlated positively in all experiments $(\mathrm{r}=0.30 * *, \mathrm{r}=0.49 * *)$. In Experiment I and II, the number of petals correlated negatively with middle leaflet breadth $\left(\mathrm{r}=0.20^{*}\right)$ and length $\left(\mathrm{r}=0.21^{*}\right)$. In 'Pima', 'Mespi' and strain 39 , the petals tended to overlap, whereas in strain 57 they rarely touched each other. Most arctic bramble strains studied here had similar petal numbers (Table 2); only strain 39 had an exceptionally high number of petals, averaging 6-16 in Experiments I and II and 8-16 in Experiment III. The more petals there were the more they overlapped. Overlapping was also affected by flower size. The average number of petals in strains 57 was 6.7 and 7.2, but its flowers were almost as big as those in strain 39. Most of the petals in strain 57 did not touch each other. Although 'Pima' had only an average number of petals (7.3 and 6.7) and its flowers were quite big, most of its petals overlapped because 'Pima' has broader petals than strain 39 .

\section{Growth and covering}

Strain 57 had the densest, and strains 33 and 39 the scantiest growth a the beginning of flower- 
Vol. 7 (1998): 455-468.

Table 2. (cont'd)

\begin{tabular}{|c|c|c|c|c|c|c|c|}
\hline \multicolumn{2}{|c|}{ No. of petals } & \multicolumn{2}{|c|}{ Length of berry } & \multicolumn{2}{|c|}{ Breadth of berry } & \multicolumn{2}{|c|}{ Weight of berry } \\
\hline \multirow[b]{2}{*}{$\begin{array}{c}\text { Experi- } \\
\text { ments I,II }\end{array}$} & \multirow[b]{2}{*}{$\begin{array}{l}\text { Experi- } \\
\text { ment III }\end{array}$} & \multicolumn{2}{|c|}{$\mathrm{mm}$} & \multicolumn{2}{|c|}{$\mathrm{mm}$} & \multicolumn{2}{|l|}{$\mathrm{g}$} \\
\hline & & $\begin{array}{c}\text { Experi- } \\
\text { ments I,II }\end{array}$ & $\begin{array}{l}\text { Experi- } \\
\text { ment III }\end{array}$ & $\begin{array}{c}\text { Experi- } \\
\text { ments I,II }\end{array}$ & $\begin{array}{l}\text { Experi- } \\
\text { ment III }\end{array}$ & $\begin{array}{l}\text { Experi- } \\
\text { ments I,II }\end{array}$ & $\begin{array}{l}\text { Experi- } \\
\text { ment III }\end{array}$ \\
\hline 7.3 & 6.7 & 9.9 & 11.3 & 11.5 & 13.3 & 0.9 & 1.1 \\
\hline 6.4 & 6.5 & 8.6 & 11.1 & 10.6 & 12.5 & 0.7 & 0.9 \\
\hline 7.3 & 6.2 & 9.4 & 12.2 & 11.8 & $14.6^{*}$ & 0.9 & $1.3^{*}$ \\
\hline 7.2 & 6.7 & 10.1 & 11.5 & 12.4 & 13.7 & 1.1 & 1.0 \\
\hline $10.6^{*}$ & $10.5^{*}$ & 10.0 & 10.8 & 11.9 & $11.8^{*}$ & 1.0 & 0.9 \\
\hline 7.2 & & 10.6 & & 12.3 & & 1.1 & \\
\hline 7.9 & & 10.2 & & 12.0 & & 1.1 & \\
\hline 14.40 & 66.33 & 3.55 & 3.08 & 3.21 & 12.10 & 2.92 & 8.10 \\
\hline 0.0001 & 0.0001 & 0.0029 & 0.0210 & 0.0060 & 0.0001 & 0.0110 & 0.0001 \\
\hline
\end{tabular}

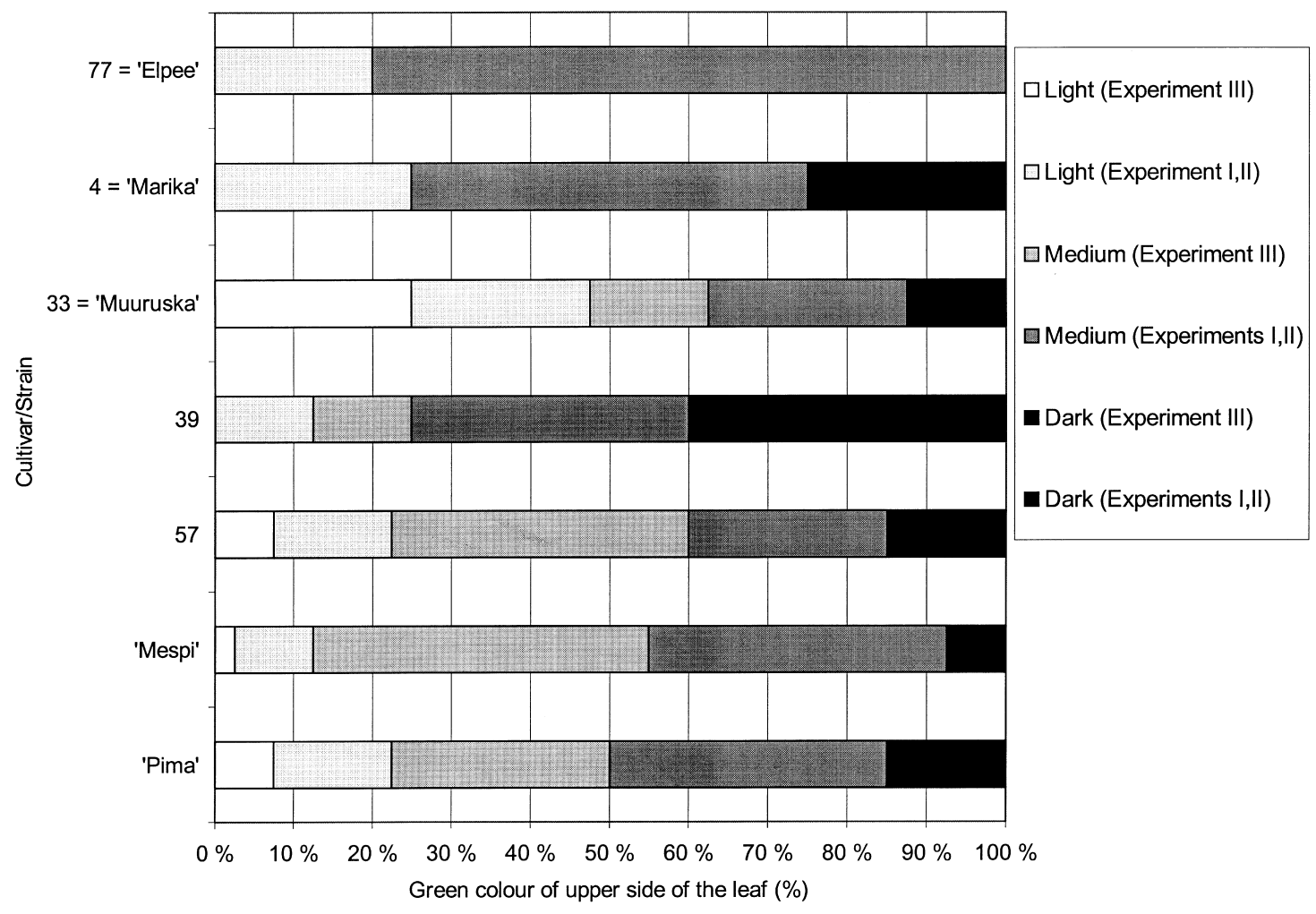

Fig. 2. Estimation of green colour in upper side of leaves of cultivars and strains of $R$. arcticus. The results for strains 77 and 4 are based on 20 leaves/strain $(=100 \%)$. The results for the other three strains and two cultivars are derived from 40 leaves/ strain $(=100 \%)$. 
Pirinen, H. et al. Description of arctic bramble cultivars

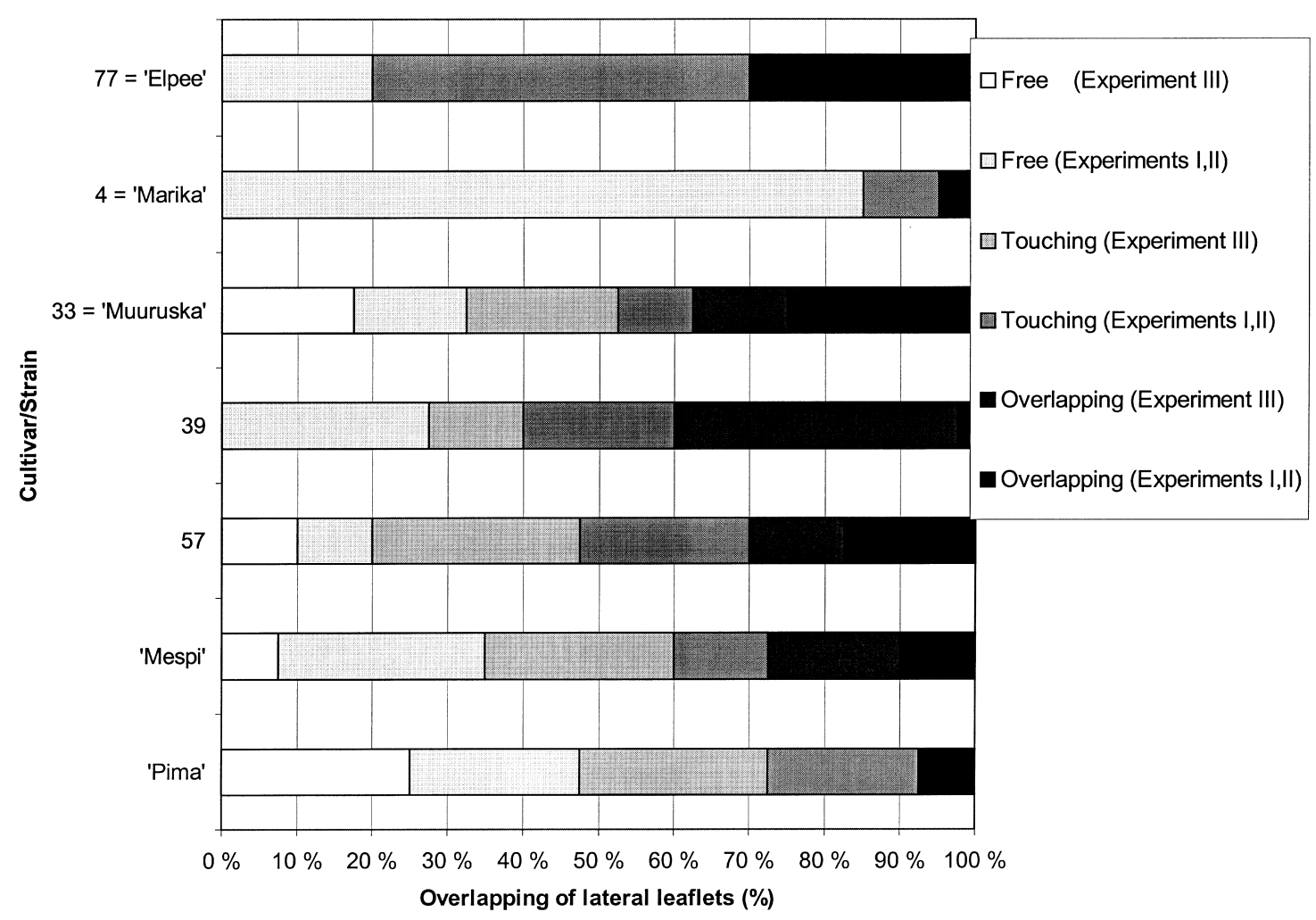

Fig. 3. Overlapping of lateral leaflets of cultivars and strains of $R$. arcticus. The results for strains 77 and 4 are based on 20 leaves/strain $(=100 \%)$. The results for the other three strains and two cultivars are derived from 40 leaves/strain $(=100 \%)$.

ing. At the beginning of harvest, strain 77 had the most vigorous growth, but the lowest covering efficiency. Strain 4 was also vigorous, being one of the best covering strains. Only 'Mespi' had a better covering efficiency in Experiment III.

\section{RAPD analysis}

RAPD analysis with 40 commercial random primers revealed a number of differences between the various arctic bramble cultivars and strains (Fig 5.). Most primers, if used alone, were not able to distinguish between all the various strains. Use of the information gathered from several primers, however, permilted the strains to be easily distinguished from one anothers. The dendrogram (Fig. 6) presents the calculated genetic distances between the cultivars and strains.
The grouping shows a close relationship between 'Pima' and 'Mespi'.

\section{Descriptions of arctic bramble cultivars}

On the basis of yield and morphological characters, three arctic bramble strains have been released for cultivation under the cultivar names Marika, Muuruska and Elpee. Like all known arctic bramble strains and cultivars, they are selfsterile, which necessitates parallel cultivation of three or more cultivars for the best production of berries. The cropping season for these cultivars starts in mid-July or by the end of July and continues until mid-August or the end of August.

Clearly the best cropper was shown to be strain 77, i.e. 'Elpee', which originates from Konnevesi. The berries have a length of 7.0 


\section{AGRICULTURAL AND FOOD SCIENCE IN FINLAND}

Vol. 7 (1998): 455-468.

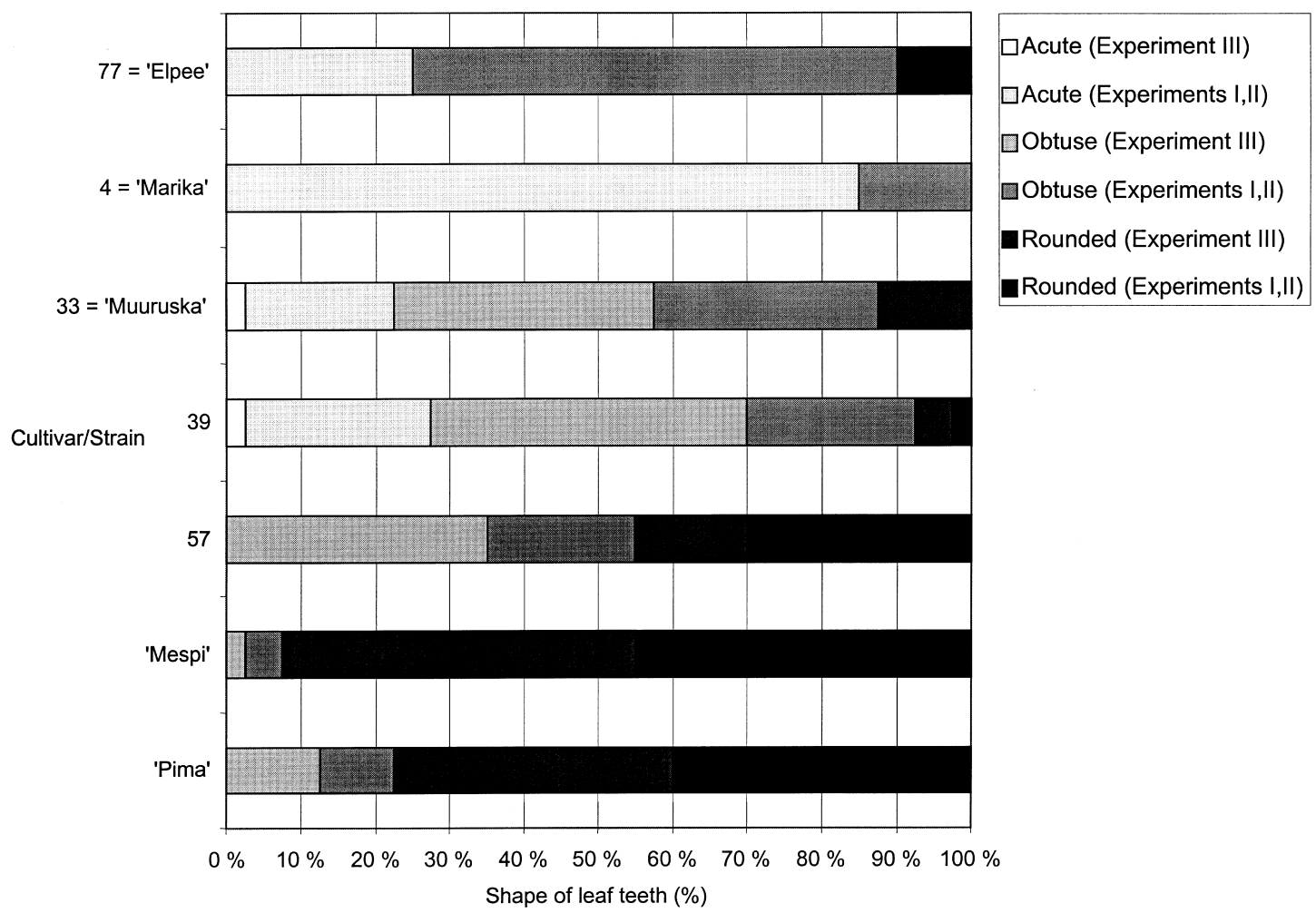

Fig. 4. Shape of leaf teeth of $R$. arcticus cultivars and strains. The results for strains 77 and 4 are based on 20 leaves/strain $(=100 \%)$. The results for the other three strains and two cultivars are derived from 40 leaves/strain $(=100 \%)$.

$14.1 \mathrm{~mm}$ and a breadth of $8.0-16.1 \mathrm{~mm}$, respectively; berry weight ranges from 0.3 to $2.1 \mathrm{~g}$. 'Elpee' has given a 2.4 times greater yield than 'Pima'. The colour of the ripe berries varies from green to purple-red and there are abundant twocoloured berries. The calyx, which is in a basin of the berry, is larger than the diameter of the fruit. The berries of 'Elpee' are more acidic and sweeter than those of 'Pima'. Flowering is abundant and the flowers are big, from 16 to $33 \mathrm{~mm}$ in diameter. The number of petals ranges from 5 to 13 and the petals clearly overlap. The calyx is smaller than the corolla. The flowers are at the same level as or beneath the foliage. The leaves are medium green in colour, the slightly concave or convex in cross-section. The relief between the veins is weak. The lateral leaflets touch each other. The shape of the leaf base is acute or obtuse and that of the teeth obtuse. The length and
1. 2. 3. 4. 5. 6. 7. Mw 8. 9. 10. 11. 12. 13. 14.

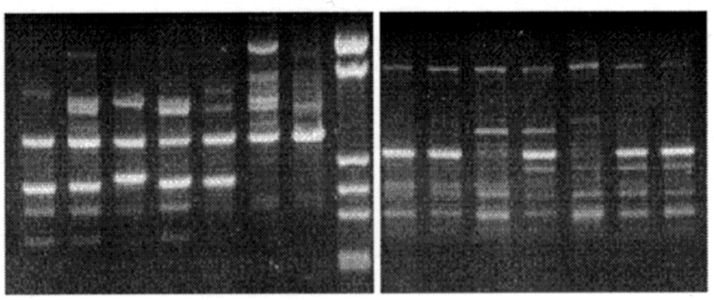

Fig. 5. RAPD analysis of $R$. arcticus DNA. Lanes 1 to 7 were amplified by primer OP E-09 and lanes 8 to 14 by OP E05 . Mw, molecular weights (from top): 1769, 1419, 676, 517, 460, 396, 241 and 214 bp. DNA samples: lanes 1 and 8, 'Elpee' (strain 04); lanes 2 and 9, 'Muuruska' (strain 33); lanes 3 and 10, strain 39; lanes 4 and 11, strain 57; lanes 5 and 12, 'Marika' (strain 77); lanes 6 and 13, 'Mespi'; lanes 7 and 14, 'Pima'.

breadth of the middle leaflet range from 30 to $52 \mathrm{~mm}$ and 20 to $37 \mathrm{~mm}$, respectively. 


\section{Pirinen, H. et al. Description of arctic bramble cultivars}

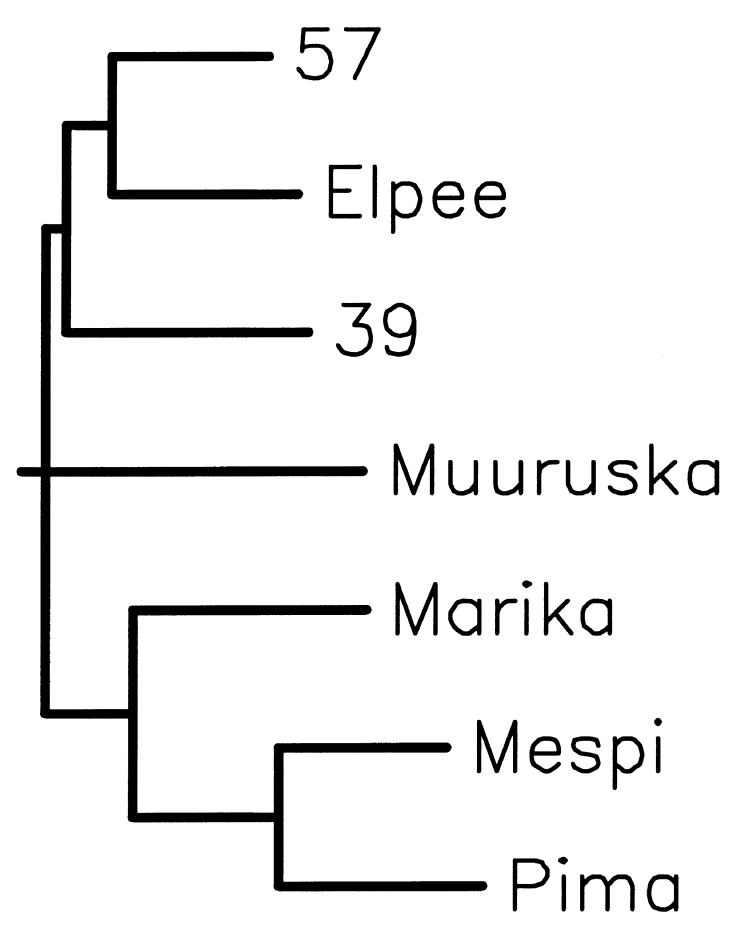

Fig. 6. Dendrogram of $R$. arcticus strains and cultivars drawn by the Neighbor-Joining method based on 52 polymorphic markers.

The second best cropper was strain 4 , i.e. 'Marika', the best yield being 2.4 times that of 'Pima'. 'Marika' originates from Laukaa. The berries have a length of $8.0-14.1 \mathrm{~mm}$ and a breadth of $8.9-15.7 \mathrm{~mm}$. The berries are big, and weight from 0.7 to $1.9 \mathrm{~g}$. In colour, the ripe berries vary from plain green to plain purple-red. The calyx is level with the berry and larger than the diameter of the fruit. The fruit is sweeter and more acidic than that of 'Pima'. Flowering is abundant and the flowers are big, from 19.0 to $29.0 \mathrm{~mm}$ in diameter. The number of petals ranges from 6 to 13. The petals may touch each other, overlap or be separate. The calyx is smaller than the corolla. The flowers are at the same level as or beneath the foliage. The colour of the leaf is medium green. The cross section of the leaf is flat and the relief between the veins is weak. Lateral leaflets do not touch each other. The shape of the leaf base and teeth is acute. The length and breadth of the middle leaflet range- from 30 to $51 \mathrm{~mm}$ and 17 to $35 \mathrm{~mm}$, respectively.

The third best cropper was strain 33, i.e. 'Muuruska', which originates from Kiiminki. It gave a 1.9 times greater yield than 'Pima'. Its berries are big, their weight ranging from 0.4 to $2.1 \mathrm{~g}$. The berries have length of 7.1-11.9 mm and a breadth of $9.4-16.1 \mathrm{~mm}$. The ripe berries vary from green to bright red in colour, and are mostly two-coloured. The calyx is in a basin or level with the berry and is larger than the diameter of the fruit. The berries of 'Muuruska' are more acidic and sweeter than those of 'Pima'. Flowering is abundant. Flower diameter ranges from 15.0 to $29.0 \mathrm{~mm}$, and the number of petals from 6 to 11 ; the petals overlap. The calyx is of the same size as the corolla. The flowers are beneath or level with the foliage. The leaves are light green in colour and concave or flat in cross-section. The relief between the veins is weak. Lateral leaflets touch each other or overlap. The shape of the leaf base is acute and that of the teeth obtuse. The length and breadth of the middle leaflet range from 32 to $55 \mathrm{~mm}$ and 18 to 37 $\mathrm{mm}$, respectively.

\section{Proposed guideline for identifying arctic bramble cultivars}

Guidelines are useful in efforts to evaluate of the characteristics of different berry strains. The distinguishing characteristics serving the identification of the various arctic bramble strains are summarised in Table 3. The most important distinctive characteristic was found to be yield, as noted also in previous studies on arctic bramble (Larsson 1970, Ryynänen 1973, Ryynänen and Dalman 1983). The present study provides some additional distinguishing factors for the identification. These include characteristics of flowers, leaves and berries, as well as growth and covering properties. In general, observations should be made on twenty plants or plant parts, and the tests should be carried out under conditions ensuring normal growth. The plant material supplied for tests should be visibly healthy, 
Vol. 7 (1998): 455-468.

Table 3. Summary of distinguishing characteristics for the identification of various $R$. arcticus strains

1. Yield

This is the most important distinctive characteristic.

The fruit yield should be recorded for at least two growing seasons.

2. Flowers

Potentially distinctive characteristics: flower abundance and diameter; number, spacing, size, shape and colour of petals; number of sepals, pistils and stamens. Observations should be made when flowers are fully opened.

3. Leaves

Potentially distinctive characteristics: length and breadth of middle leaflet; shape of teeth and base; shade of green colour of upper side of leaf; overlapping of lateral leaflets, cross-section of leaf. All leaves should be collected from the same location in the stem. Observations should be made at the beginning of harvest.

4. Berries

Potentially distinctive characteristics: length, width, weight, colour. Fruit sweetness and acidity can be studied with sensory and chemical tests. Observations should be made from the second harvest.

5. Growth and covering

Potentially distinctive characteristics: cane length; vigour of growth; covering efficiency; plant density. Observations should be made at the beginning of flowering.

neither lacking in vigour nor affected by any important pests or diseases; it is particularly important that arctic bramble showed to be free of viruses and downy mildew (Peronospora rubi Rabenh). The strains should be tested in at least two locations at the same time to eliminate environmental effects, and morphological observations should be made during two growing seasons. The characteristics summarised here can be used to prepare guidelines for the conducting of tests for distinctness, homogeneity and stability of arctic bramble (Rubus arcticus L.). The same characteristics should also be applicable to arctic bramble hybrids (Rubus arcticus L. nothosubsp. stellarcticus G. Larsson).

\section{Discussion}

A strain that is to be described as a new cultivar must have characteristics distinguishing it from other strains of the same species. The most valuable properties of the new strain must also be equal to or better than those of the present cultivars. On the basis of yield and morphological characteristics and the results of genetic analysis, we were able to differentiate between arctic bramble cultivars and strains. Three of the strains studied, i.e. 33, 4 and 77, gave higher yields than 'Pima' or 'Mespi' in the fourth year after planting. According to Kokko et al. (1993), the same strains have given a better yield in the second and third years after planting, too. These strains were originally collected from an area where arctic bramble used to be quite common and berry production high (Tammisola 1988, Kokko et al. 1993). Although strains 4 and 77 were not included in Experiment III, their high yielding properties became apparent in Experiment I. The yield varied from one experiment to another, possibly due to differences in environments and planting times. Experiments II and III were planted one year later than Experiment I. Ryynänen (1973) found that arctic bramble yields reach their maximum in the fourth year after planting.

The colour of the berries varied between the strains but also within a strain. Ryynänen (1973) reported a similar finding. In sensory tests, the variation between the experiments in the sweetness and acidity of the fresh berries was partly due to the different observers. The result of Experiment III was consistent with that of chemical analyses from berries collected from the experiment in fields I and II (Häkkinen et al. 1994), which partly explains their inconsistency with sensory tests. Accordingly, strains 57 and 39 not only had the most acidic and sweetest taste, but they also had high sucrose and acid contents. Strain 33 also had high contents of fructose and sucrose (Häkkinen et al. 1994); its taste was only medium in Experiment III, but the sweetest in Experiments I and II.

We collected the leaves randomly without 


\section{Pirinen, H. et al. Description of arctic bramble cultivars}

taking into account the differences in morphology between the base, middle and top of the stem (Kalela 1963). The first leaves are often simpler in shape than the later ones (Street and Öpik 1970). Although arctic bramble plants have a short stem and only a few leaves, we might have been able to distinguish leaf characteristics better if we had taken the various stem parts into account in sampling. On the other hand, Ryynänen (1973) reported that each arctic bramble strain has typical leaf characteristics irrespective of where it is collected from. According to Wareing and Phillips (1981), propagation by tissue culture can affect leaf morphology, as is shown in strawberry (Fragaria ananassa Duch.), black currant (Ribes nigrum L.) and apple (Malus $\mathrm{x}$ domestica Borkh.). It might be worthwhile to investigate such effects in arctic bramble, too.

Differences in leaf shape/morphology were best shown in cross-sections, teeth shape and overlapping of lateral leaflets; these characteristics distinguish between strains 4 and 77. According to Pyykkö (1975), the climatic factors with the greatest effects on leaves are radiation, temperature, humidity and wind, whereas the shape of the leaves, dentation of the margin and petiole length are affected by environmental factors. According to Lohi (1974), Rubus chamaemorus L. has large leaves in shady places and small leaves in open sites. Schwabe (1963) has shown the environmental effect on the dentation of leaf margin in chrysanthemum, with maximum leaf dissection in warm temperatures, and minimum in cold temperatures.

According to Stebbins (1974), flower structure, especially the number of floral leaves, tends to be rather constant; fluctuation in corolla lobe number is due to genetic variation, which may be affected by selection in the environment. Similar conclusions have been drawn in studies on cloudberry in which the number of pistils per flower remained unaffected by environmental conditions but berry weight and yield were influenced by air temperature, rain and wind (Rapp 1989). Arctic bramble has maintained considerable genetic variation with the aid of its longlasting seeds and obligate cross-fertilisation due to self-incompatibility. The strains used here originated from different parts of Finland representing rather different environments. Genetic differences in phenology between such distant origins were already observed in the first experimental field (Tammisola 1988).

The results presented here show that flower size is a good distinguishing characteristic, although its effect on yield is controversial. According to Ryynänen (1973), larger flowers have fewer carpels, which should have an adverse effect on berry size and yield. On the other hand, large flowers can produce larger druplets or attract more pollinators, thus ensuring more complete fertilisation. Flowering was abundant in strains 33 and 4, which also had the greatest yields. This was not unexpected, since the more flowers there are the more berries will be produced, provided that efficient cross-pollination occurs. According to Oksanen (1989), abundant flowering attracts pollinators and thus ensures more complete pollination.

Growth and covering efficiency indicate how much the plant allocates energy to its vegetative growth. Thus it was not surprising that strain 33, which gave a high yield, had the scantiest covering efficiency. Strain 4, however, which was vigorous and had the best covering efficiency, also gave a high yield. Therefore, in addition to general environmental limits, there must be strain-specific genetic factors controlling the allocation of energy for berry production and vegetative growth.

RAPD analysis has been developed as a fast and simple test to accurately characterise raspberry cultivars (Parent et al. 1993). Graham and McNicol (1995) examined the ability of RAPD markers to determine the relationship within and between Rubus species. Here, RAPD analysis was able to distinguish between the various arctic bramble cultivars and strains and to identify the close relationship between 'Mespi' and 'Pima'. In special cases, this method can be recommended for cultivar identification. However, it is a special technique and causes problems in reproducibility. It is not therefore suitable for routine use, and we do not recommend it as a criterion for arctic bramble cultivar identification. 
Vol. 7 (1998): 455-468.

\section{References}

Doyle, J.J. \& Doyle, J.L. 1990. Isolation of plant DNA from fresh tissue. Focus 12: 13-15.

Graham, J. \& McNicol, R.J. 1995. An examination of the ability of RAPD markers to determine the relationship within and between Rubus species. Theoretical and Applied Genetics 90: 1128-1132.

Häkkinen, S., Kokko, H. \& Kärenlampi, S. 1994. Sugars and organic acids in clones and cultivars of arctic bramble and hybrid. Sensory evaluation of juices and jellies. Agricultural Science in Finland 4: 385-395.

Kalela, A. 1963. Kasviorganologia. Otava. 180 p.

Kokko, H., Kärenlampi, S., Rissanen, E., Tammisola, J. \& Kärenlampi, L. 1993. EY-markkinakelpoisten tuotteiden etsiminen ja kehittäminen: mesimarjan uudet kannat. Raportti vuosina 1990-1992 suoritetuista tutkimuksista. Kuopio. 28 p.

- Kivineva, M. \& Kärenlampi, S.O. 1996. Single-step immunocapture RT-PCR in the detection of raspberry bushy dwarf virus. Biotechniques 20: 842-846.

Larsson, E.K.G. 1970. Development and cultivation of northern small fruits in the genus Rubus L. Ph.D. thesis, Uppsala Landbrukshögskolan. Uppsala. Sverige.

Lohi, K. 1974. Variation between cloudberries (Rubus chamaemorus L.) in different habitats. Aquilo Serie Botanica 13: 1-9.

Maa- ja metsätalousministeriön tietopalvelukeskus 1996. Puutarhayritysrekisteri 1995. Maa- ja metsätalous 1996: 1. Hakapaino Oy. Helsinki. p. 56-69.

Oksanen, J. 1989. Mesimarja. Savon Luonto 20: 2-6.

Paasisalo, S. \& Kokko, H. 1991. Mesimarjan viljely. Kuopio. $16 \mathrm{p}$.

Parent, J.-G., Fortin, M.G. \& Pagé, D. 1993. Identification de cultivars de framboisier par l'analyse d'AND polymorphe amplifié au hasard (RAPD). Canadian Journal of Plant Science 73: 1115-1122.
Pyykkö, M. 1975. Kasvianatomia. Hämeenlinna. p. 145226.

Rapp, K. 1989. Number of pistils, an alternative criterion when selecting for high productivity in Rubus. Norwegian Journal of Agricultural Sciences 3: 29-32.

Ryynänen, A. 1972. Arctic bramble (Rubus arcticus L.), a new cultivated plant. Annales Agriculturae Fenniae 11: 170-173.

- 1973. Rubus arcticus L. and its cultivation. Annales Agriculturae Fenniae 12: 1-76.

- \& Dalman, P. 1983. A new variety of arctic bramble 'Pima'. Annales Agriculturae Fenniae 22: 1-7.

Schwabe, W.W. 1963. Morphogenetic responses to climate. In: Evans, L.T. (ed.) Environmental control of plant growth. Academic Press, New York and London. p. 311-336.

Stebbins, G.L. 1974. Flowering plants. Evolution above the species level. Edward Arnold Ltd. London. 399 p.

Street, H.E. \& Öpik, H. 1970. The physiology of flowering plants: Their growth and development. Edward Arnold Ltd. London. 263 p.

Tammisola, J. 1988. Incompatibility classes and fruit set in natural populations of arctic bramble (Rubus arcticus L.) in Finland. Journal of Agricultural Science in Finland 60: 323-446.

UPOV 1984. Guidelines for the conduct of tests for distinctness, homogeneity and stability. Strawberry (Fragaria L.). UPOV publication TG/22/6. Geneve. 20 p.

- 1986. Guidelines for the conduct of tests for distinctness, homogeneity and stability. Raspberry $(R u$ bus idaeus L.). UPOV publication TG/43/6. Geneve. $24 \mathrm{p}$.

Wareing, P.F. \& Phillips, I.D.J. 1981. Growth and differentation in plants. 3rd ed. Pergamon Press. Oxford. $343 \mathrm{p}$. 
Pirinen, H. et al. Description of arctic bramble cultivars

\title{
SELOSTUS
}

\section{Kolmen uuden mesimarjalajikkeen kuvaukset ja lajikekuvausohjeet mesimarjalle ja jalomaaraimelle}

\author{
Heli Pirinen, Pirjo Dalman, Sirpa Kärenlampi, Jussi Tammisola ja Harri Kokko \\ Kuopion yliopisto, Maatalouden tutkimuskeskus ja Helsingin yliopisto
}

\begin{abstract}
Uusia mesimarjalajikkeita (Rubus arcticus L.) tarvitaan lisää, sillä populaatiossa on oltava ainakin kolmea erilaista kantaa hyvän pölytyksen ja satotason saavuttamiseksi. Tässä tutkimuksessa on löydetty kolme uutta hyväsatoista lajiketta viljelyyn 'Piman' ja 'Mespin' rinnalle. Lajikkeet on nyt nimetty 'Marikaksi', 'Muuruskaksi' ja 'Elpeeksi'.

Uuden lajikkeen on erottava muista saman lajin lajikkeista yhden tai useamman ominaisuuden suhteen. Ominaisuus voi olla morfologinen, fysikaalinen, sytologinen, kemiallinen tai biokemiallinen. Morfologisten tuntomerkkien erottamiseksi UPOV-järjestö (Union pour la Protection des Obtentions Vegetales) on kehittänyt lajikekuvausohjeet $\mathrm{mm}$. mansikalle (Fragaria x ananassa Duch.) ja vadelmalle (Rubus idaeus L.). Mesimarjalle tällaisia ohjeita ei ole. Tämän tutkimuksen tavoitteena oli kuvata uusia mesimarjalajikkeita ja tehdä mesimarjalle lajikekuvausohjeet muuntamalla UPOV-järjestön mansikalle ja vadelmalle tekemiä ohjeita mesimarjalle soveltuviksi.
\end{abstract}

Tutkimuksessa oli mukana viisi luonnonkantaa ja kaksi lajiketta (Pima, Mespi). Kantojen ja lajikkeiden morfologiaa ja satoa tutkittiin Maatalouden tutkimuskeskuksen Kainuun tutkimusasemalla ja Muuruveden maatalous- ja puutarhaoppilaitoksella kesällä 1994. Lisäksi vertailtiin eri mesimarjojen DNA:ta RAPD-analyysillä. Tutkimuksessa sadon määrän ja laadun suhteen 'Pimaa' ja 'Mespiä' parempia kantoja olivat 'Marika', 'Muuruska' ja 'Elpee'. 'Marika' ja 'Muuruska' tuottivat 2,4-kertaisen ja 'Elpee' 1,9kertaisen sadon verrattuna nykyisiin lajikkeisiin. Morfologisista ominaisuuksista kukan ja lehden ominaisuudet, eli terälehtien määrä, kukan koko sekä lehden koko, muoto ja väritys erottivat kantoja parhaiten. Erottavien tuntomerkkien perusteella mesimarjalle on laadittu lajikekuvausohjeet, joita voidaan soveltaa myös jalomaaraimen (Rubus arcticus $\mathrm{L}$. nothosubsp. stellarcticus G. Larsson) lajikkeiden kuvaukseen. 